\title{
The Concept of Justice in People's Lives According To Teilhard de Chardin Contributes To The Strengthening of The Character of The Younger Generation In Indonesia
}

\author{
Sri Sudarsih* \\ Department of History, Faculty of Humanities, University of Diponegoro, Kampus Undip Tembalang, \\ Semarang - 50275, Jawa Tengah, Indonesia
}

\begin{abstract}
This study aims to describe the life together in society according to Teilhard de Chardin. Then the researchers tried to reveal the value of justice in it. This research is a qualitative research. The basis of this research theory is the value of justice, while the object of study is life together in society according to Teilhard de Chardin. The methodical elements used are description, interpretation, and analysis-synthesis. The results achieved are as follows: the value of justice in the relations between individuals and society is closely related to human nature. Every individual has freedom in building relationships with others. The value of justice is reflected in the form of mutual respect, giving and receiving, and loving. Love becomes the energy for the creation of justice in society. Justice according to Teilhard de Chardin is justice towards oneself, other people or the community, and God. The value of justice can be used as a basis for strengthening the character of younger generation in Indonesia.
\end{abstract}

\section{Introduction}

Humans are social creatures, meaning that human life can never be separated from its social environment. The reality is that humans cannot live without the presence of others. Humans always need other people in the same space and time and utilize the limited availability of nature as a basis for meeting their needs. But on the one hand humans need each other, on the other hand they compete with one another. Therefore, the actions of each individual should also pay attention to the interests of others.

As human beings who have reason, every individual should be able to maintain harmony in people's lives for peace. As members of the community, each individual has moral obligations, including the obligation to respect and love each other. But their awareness of that at the level of reality is still minimal. The phenomenon that arises in society today is the lower sense of concern between individuals. Sense of competition is more prominent than mutual need. Another symptom is the fading of mutual trust. The presence of others is felt as a threat, not a need. As a result humans are sometimes very emotional and angry when faced

* Corresponding author: srisudarsih012005@yahoo.com 
with various problems of life. Whereas humans are creatures that are given the gift of reason by God, which should be used as controllers of feelings that are volatile and vacillating.

This reality shows that currently the community is experiencing a moral crisis and value disorientation. The community is experiencing a conceptual wavering about the principles that are believed to bring logical consequences to the uncertainty of the foundation in addressing the various problems faced. Based on these reasons, the way of thinking and behaving in certain societies goes beyond the limits of ethical propriety, religion, and cultural institutions [1].

Progress in the field of communication and information seems to cause patterns of life that only prioritizes pleasure. A further impact is the growth of the qualities of egoism. Utilization of technology that is widely developed in society is a gadget. Sophisticated gadgets spoil consumers with features that are very complete and attractive so that sometimes some individuals become complacent. Humans have been mastered with technology that brings logical consequences to the weakening of the character of young generation. Humans should master technology so that it provides positive benefits for life. The advancement of science and technology should be useful for the welfare, intelligence, and dignity, not the other way around, instead forming an instant generation, lazy to struggle. Even though we are pragmatic, we should not abandon the ideology of struggle.

The nature of egoism that is symptomatic in society has an impact on the lack of concern for other individuals. Justice among people began to be ignored.

\section{Methods}

The initial step of this research is the researcher collects literature related to the theoretical foundation and object of study. The next step is to read the literature then systematize. This research is a qualitative research. The theoretical foundation used is the value of justice, while the object of study is social life according to Teilhard de Chardin. The methodical elements used in this study are description, interpretation, and analysis-synthesis.

\section{Results and Discussion}

\subsection{Understanding the Value of Justice}

Value is the inherent quality of something. Values in understanding Bertens, namely: first, values are always related to the subject. Value is not possible without the role of the subject as an appraiser. Second, the value is symptomatic in practical contexts. Values will not exist by merely a theoretical approach. Third, values are related to the properties that are 'added' by the subject on the object [2].

While justice comes from the word 'fair'. Fair means compatibility with the nature of justice. Understanding the nature of justice in the second principle of Pancasila is fair and civilized. This terminology is understood as fair to oneself, others, and God. Talk about justice can never be separated from human nature. The unity of human nature according to Notonagoro (in Kaelan) is monopluralist. The elements of human nature are monodualist, the composition of human nature consisting of soul and body; individual and social beings; personal beings and God's creatures. The noble human nature that is in accordance with human nature is tabiat saleh. Tabiat saleh:

a. Watak kebijaksanaan (character of wisdom). The nature of wisdom implies that every attitude and behavior of humans is always based on reason, sense, and will. The mind 
gives consideration to the action that must be done, the sense of giving aesthetic consideration, the will to give consideration that an action is done or not based on ethical considerations.

b. Watak keadilan (character of justice). Fair character must be reflected in every attitude and behavior of humans. Fair means the ability to carry out obligations and give to others who are entitled to.

c. Watak kesederhanaan (simplicity). Simplicity means that every attitude and behavior of human beings must reflect simplicity and avoid luxury and enjoyment as an expression of transgressions.

d. Watak keteguhan (character of constancy). Character of constancy is the ability to limit oneself to grief or good things [3].

\subsection{Teilhard's Core Thinking About Community Life}

Teilhard asserted in his book entitled Phenomenon of Man that humans are the center and the front line of evolution. Evolution according to Teilhard reached its peak in humans, but humans are not the end of the evolutionary process. Therefore the evolution of the future is very different from the previous evolution because humans are creatures that have freedom. Humans continue to develop at a certain point. Teilhard tried to continue the lines of evolutionism towards the future. His attention to the future has to do with the belief that evolution must be understood as progress. Evolution in Teilhard's understanding does not give pessimism but the evolution of the cosmos will not fail. Teilhard was optimistic because he observed the existence of a phenomenon called planetation. Technology provides a major role to realize the process of planetation, which is the unity of all peoples and cultures. The entire evolution of the world including human history moves at the same goal at the point of perfection, the Omega Point. God is Alpha and Omega. Spiritualization reaches its fullness on a supra-human level. But Teilhard asserted that the Omega point was not entirely included in the future because in this process of life it is real and active as an energy that unites humans and synthesizes the entire process of evolution and history. Teilhard's main ideas is the theory of evolution. Evolution occurs because of the law of complexity of consciousness. This law emphasizes the close relationship between the complexity of the material structure and the intensity of consciousness. Both are in a balanced and harmonious unity [4]. Inside and outside are no higher or dominant but both are in harmony.

Humans are the center and front line of evolution. Humans continue to develop as free beings. Humans in their development increasingly aware of the importance of living in groups so that humans form society. The existence of other people is imperative because in reality humans cannot live alone but need others. Teilhard understood that humans must live in togetherness. Togetherness will make someone in a relationship with cooperation between individuals. Every individual has an obligation to give and take so that they have broad insights. In that relationship the individual remains an autonomous being and discovers his identity.

Building relationships between individuals causes each individual to find his true self. Humans remain autonomous and do not lose their freedom, on the contrary it will increasingly have high quality. Freedom according to Suseno is a sign of the expression of human dignity because freedom proves that humans are autonomous beings who can make choices about their own attitudes and actions. Every coercion is felt to us as bad, painful, even insulting as an autonomous and dignified creature. Forcing others means ignoring the dignity of capable human beings and being aware of their attitudes and actions. Humans feel most humiliated when threatened, coerced and persuaded to do something that is against their conscience. Humans feel happy to do something if asked, but if our freedom and dignity are still respected. Indeed freedom is the crown of our dignity as human beings [5]. 
Freedom here presupposes physical freedom as well as spiritual freedom that underlies responsible freedom. The freedom of each individual is not absolute, his freedom is limited by the freedom of other individuals.

Teilhard asserts:

To be fully ourselves it is the opposite direction, in the direction of convergence with all the rest, that we must advance-towards the other. The peak of ouselves, the acme of our originalty, it is not our individuality but our peson; and according to the evolutionary structure of the world, we can only sign our person by uniting together. There is no mind without synthesis [6].

Furthermore, to achieve harmony in togetherness, Teilhard states:

The individual in a human society in process of collective organisation has not the right to remain inactive, that is to say, not to seek to develop himself to his fullest extent: because upon his individual perfection depends the perfection of all his fellows. Whatever measures may be adopted to this end, there is one major principle which must be affirmed and always upheld: in no circumstances, and for no reason, must the forces of collectivity compel the individual to deform of falsify himslef (by accepting as true what he sees to be false, for example, which is to lie to himself). Every limitation imposed on the autonomy of the element by the power, of the group must, if it is to be justified, operate only in conformity with the free internal structure of the element. Otherwise a fundamental disharmony will arise in the very heart of the collective human organism [7].

Understanding of the above confirms the reciprocal relationship between the individual and the social environment. Individual and social life develops in a balanced and harmonious manner so as to create a harmonious atmosphere. Humans are autonomous creatures so to develop themselves still have freedom in carrying out their obligations. Individuals in their social environment are free to determine their development without coercion from outside. To achieve that all requires the role of love.

Love as energy. Love is energy in humans that is able to unite humans [6]. Needs and problems are increasingly complex, so humans increasingly need the presence of other individuals. They need each other. Therefore, the existence of others is imperative. Love as a cosmic power is not affected by other forces. This power is difficult to understand in real life but its presence can be felt. But in principle love has a very deep meaning and is an energy that is able to provide the strength to always interpret this life positively. Love as a unifying force between individuals.

Love as a cosmic power is related to the activeness of each individual. The potential for love can be manifested through being active in opening up to the world and playing a role in it. According to Teilhard, love means acting and taking an active role in social life. This attitude is an attempt to treat individuals as whole human beings [8]. Love energy can provide motivation to always play an active role in relation to social life.

Love is able to direct humans to the goal of every development at the Omega Point [6]. The Omega point can also be interpreted as a point of perfection. Humans must be optimistic to be able to reach this point.

\subsection{The value of Justice in the Concept of Community Life}

Teilhard did not discuss justice specifically, but the values of justice can be found in his theory of human relations as individual and social beings, or concepts of human nature. It means that justice always happens in a life together. Interaction and relations in this togetherness, every individual has freedom of action. But his freedom is not absolute because this freedom is limited by the freedom of other individuals.

Justice can be realized in the life of people who are always developing. That can be realized if every individual has a sense of love. The demand for life needs is getting higher 
along with the increasingly complex development of life. To meet this need, of course, every individual needs the presence and cooperation with others. To achieve that there are obligations that must be carried out by each individual. One of the obligations of individuals is to make themselves as individuals who have noble character. This character is needed to establish a harmonious collaboration. To achieve that, every individual in the life of society is obliged to love and respect each other. Humans are able to do justice because it makes love the basis of his life.

Values of justice must be applied in shared life so that this process makes each individual achieve personalization rather than the other way around, namely individualization and extreme racism. Both of them can actually hinder personality from achieving convergence. In the life of people who apply the values of justice, each individual can provide and get fulfillment (more quality).

Injustices that often occur in society are marked by the emergence of a variety of problems. In response to this, individuals must be optimistic because there are still forces that have a unifying force, namely love. Justice means not prioritizing individual interests while making each individual in the community towards personalization in regular integration with society. But justice is reflected by the mutual relationship between individuals in social life. Individual and social life are two components that must be developed in harmony and balance. Individuals have an obligation to develop their personality and potential. But individuals have the right in society not to be forced or damaged, but their dignity and respect must be respected. Justice has logical consequences for a perfect life.

\subsection{Contribution of the Teilhard Justice Concept to Strengthening Character}

Five main character values: First, the value of religious character that reflects the faith in God that is manifested in carrying out religious teachings, for example, respecting religious differences, tolerance, harmony, and having a firm stand. Second, the value of nationalist character is a way of thinking and behaving which shows loyalty, concern, and respect for language, physical environment, social, economic, cultural, political environment of the nation, placing national and state interests above individuals and groups . Third, the value of the character of integrity, reflects the attitude of responsibility as a citizen, participation in people's lives, and acting on the truth. Fourth, the value of independent character is an attitude and behavior that does not depend on others, has a good work ethic, is empowered, and is creative. Fifth, the value of mutual cooperation character is an act of appreciating cooperation in solving problems, establishing communication and strengthening friendships, and having high empathy and a sense of solidarity [9].

The value of justice in Teilhard's perspective can be the basis for strengthening the character of young people in Indonesia. This is based on the reason that technological advancements in the field of information and telecommunications contribute to shaping the young generation of instant character. Instant character is attitudes that have degraded their sense of struggle and tend to be results oriented rather than process oriented. The attitude of individuals who are more likely to prioritize the results are vulnerable to failure because this attitude does not value the process. Every process-oriented individual has a wiser and stronger attitude in managing failure because he or she is aware that results are understood as bonuses for a process. Now the young generation needs to strengthen the importance of the value of justice in people's lives. The value of justice is underlying in strengthening the character of individuals to become quality individuals. This value will provide unlimited energy in the search for identity. While the value of love which is at the core of Teilhard's philosophical teachings, teaches that love is the basis of development for everything towards perfection. Love becomes the driving force of change for the better. Love becomes a vital element in relationships between individuals in society so that awareness is created for 
mutual respect, empathy for others, and a sense of struggle. These values are important in strengthening the formation of the character of the younger generation.

\section{Conclusion}

The value of justice is reflected in Teilhard's theory of the relationship between individuals and other individuals (society), or the concept of human nature. Justice becomes the core for the realization of harmony in a shared life. Justice in society can be realized if each individual has a sense of love. While the application of the values of justice in people's lives can lead each individual towards personalization. This personalization is a form that every individual is able to crystallize the values in him. Javanese formulates these values wus kasarira (already private). The value in this case is the value of justice in Teilhard's perspective.

\section{References}

1. I. Widisuseno, "Penguatan Pendidikan Kewarganegaraan Melalui Isu dan Tantangannya", presented at Pentaloka Dosen Kewarganegaraan in April 2010 in Rindam Magelang (2010).

2. K. Bertens, Etika. Jakarta: Gramedia Pustaka Utama, 151-152 (2011).

3. Kaelan, Filsafat Pancasila: Pandangan Hidup Bangsa Indonesia, Yogyakarta: Paradigma, 161-168 (2002).

4. K. Bertens, Filsafat Barat Kontemporer; Jilid II: Prancis, Jakarta: Gramedia Pustaka Utama, 37-45 (2001).

5. F. M. Suseno, Etika Dasar, Yogyakarta: Kanisius, 26 (2001).

6. T. De Chardin, The Phenomenon of Man, London: Jame's Place, 258-264 (1959).

7. T. De Chardin, The Future of Man, New York: Harper \& Row, 194-195 (1964).

8. F. Dahler, E. Budianta, Asal dan Tujuan Manusia, Yogyakarta: Kanisius, 131 (1984).

9. Kementerian Pendidikan dan Kebudayaan, Penguatan Pendidikan Karakter Jadi Pintu Masuk Pembenahan Pendidikan Nasional (2017) https://www.kemdikbud.go.id/main/blog/2017/07/penguatan-pendidikan-karakter-jadipintu-masuk-pembenahan-pendidikan-nasional. 